\title{
Correlation of the aqueous humor total antioxidant capacity, total oxidant status, and levels of IL-6 and VEGF with diabetic retinopathy status
}

\author{
Correlação entre níveis de humor aquoso da capacidade antioxidante \\ total, estado oxidante total, IL-6, VEGF e status da retinopatia diabética
}

\author{
Erdinç Bozkurt', Burçin Çakır', Erkan Çelik', Emine Doğan', Turgay Uçak², Gürsoy Alagöz \\ 1. Sakarya University Education and Research Hospital, Sakarya, Turkey. \\ 2. Erzincan University Education and Research Hospital, Erzincan, Turkey.
}

\begin{abstract}
Purpose: We aimed to compare the aqueous humor total oxidant status, total antioxidant capacity, and levels of interleukin- 6 and vascular endothelial growth factor between patients with diabetic retinopathy and controls and to correlate these levels with the DR status. Methods: Patients who underwent cataract surgery were enrolled. The first group (control group) comprised patients without diabetes; the second group comprised diabetic patients without retinopathy; the third group comprised patients with nonproliferative diabetic retinopathy; and the fourth group comprised patients with proliferative diabetic retinopathy. All patients underwent full ophthalmologic examination before cataract surgery. Prior to surgery, samples of aqueous humor sampling were obtained and stored at $-80^{\circ} \mathrm{C}$. Total antioxidant capacity, total oxidant status, and levels interleukin- 6 and vascular endothelial growth factor were investigated in these samples and correlated with diabetic retinopathy status. Results: This study analyzed 86 pairs of eyes of 86 patients. All groups were statistically similar in age and sex, but the total antioxidant capacity was lowest in patients with proliferative diabetic retinopathy. Moreover, the total oxidant status and levels of vascular endothelial growth factor and interleukin- 6 were found to slightly increase according to the retinopathy status. Conclusion: Oxidative stress, interleukin-6, and vascular endothelial growth factor in the aqueous humor seem to play important roles in the pathogenesis of diabetic retinopathy, especially in the proliferative type.
\end{abstract}

Submitted for publication: October 18, 2017

Accepted for publication: June 22, 2018

Funding: No specific financial support was available for this study.

Disclosure of potential conflicts of interest: None of the authors have any potential conflicts of interest to disclose.

Corresponding author: Burçin Çakır

Sakarya University Education and Research Hospital - Sakarya - Turkey

E-mail: b_koklu@yahoo.com

Approved by the following research ethics committee: Sakarya University Education and Research Hospital (\# 12:16214662/050.01.04/74).
Keywords: Diabetic retinopathy; Oxidative stress; Interleukin-6; Vascular endothelial growth factor A; Aqueous humor

RESUMO | Objetivo: Procurou-se comparar o humor aquoso estado oxidante total, a capacidade antioxidante total, e os níveis de interleucina- 6 e do fator de crescimento endotelial vascular entre pacientes com retinopatia diabética e em indivíduos controles, e correlacionar esses níveis com o status da retinopatia diabética. Métodos: Pacientes submetidos à cirurgia de catarata foram incluídos. O primeiro grupo (grupo controle) foi composto por pacientes sem diabetes; o segundo grupo inclui pacientes diabéticos sem retinopatia; o terceiro grupo inclui pacientes com retinopatia diabética não proliferativa; e o quarto grupo inclui pacientes com retinopatia diabética proliferativa. Todos os pacientes foram submetidos a exame oftalmológico completo antes da cirurgia de catarata. Antes da cirurgia, amostras de humor aquoso foram obtidas e armazenadas a $-80^{\circ} \mathrm{C}$. A capacidade antioxidante total, o estado oxidante total e os níveis de interleucina- 6 e fator de crescimento endotelial vascular foram investigados nessas amostras e correlacionados com o status da retinopatia diabética. Resultados: Este estudo analisou 86 pares de olhos de 86 pacientes. Todos os grupos foram estatisticamente semelhantes em idade e sexo, mas a capacidade antioxidante total foi menor em pacientes com retinopatia diabética proliferativa. Além disso, o estado oxidante total e os níveis de fator de crescimento endotelial vascular e interleucina- 6 estavam ligeiramente aumentados de acordo com o status da retinopatia. Conclusão: O estresse oxidativo, a interleucina- 6 e o fator de crescimento endotelial vascular no humor aquoso parecem desempenhar papel importante na patogênese da retinopatia diabética, especialmente no tipo proliferativo.

Descritores: Retinopatia diabética; Estresse oxidativo; Interleucina-6; Fator A de crescimento do endotélio vascular; Humor Aquoso

\section{INTRODUCTION}

Diabetes mellitus (DM) is a common disease worldwide, and diabetic retinopathy (DR) is one of the main causes 
of blindness ${ }^{(1,2)}$. In vitro and in vivo studies have suggested that increased oxidative stress plays an important role in the pathogenesis of diabetic complications, including retinopathy ${ }^{(3,4)}$. In animals with experimentally induced diabetes, the retinal levels of enzymes, such as superoxide dismutase (SOD), glutathione reductase, glutathione peroxidase, and catalase, were shown to be decreased; as a consequence, theintraretinal levels of the potent antioxidant, glutathione, were also decreased in diabetic rats $^{(5-7)}$. In recent studies, oxidative stress parameters were measured in the blood and were found to be correlated with the DR status ${ }^{(8,9)}$. However, only few studies have investigated these parameters in the other body fluids, such as the aqueous humor $(\mathrm{AH})$ and vitreous $^{(10,11)}$. In the past, investigation of the levels of antioxidants and metals was performed both separately and as total oxidant status (TOS) and total antioxidant capacity (TAC). The latter approach may be more rational because the antioxidants may affect each other in either a synergistic or antagonistic pattern.

The aldose reductase pathway, growth factors, and an increase in oxidative stress factors can cause damage in the retinal blood supply, leading to capillary occlusion and retinal ischemia. These processes involve the secretion of several growth factors, including interleukin (IL)-6, vascular endothelial growth factor (VEGF), basic fibroblast growth factor, tumor necrosis factor- $\alpha$, IL-1 $\beta$, hepatocyte growth factor, monocyte chemoattractant protein-1, and IL-8. Among these, VEGF and IL- 6 have beeen shoen to cause conformational changes in the tight junctions of the retinal vascular endothelial cells and to play a major role in the increased vascular permeability and breakdown of the blood retinal barrier in diabetic eyes ${ }^{(12)}$.

In this study, we aimed to investigate and compare the TOS, TAC, and levels of IL- 6 and VEGF in the AH between patients with DR and control patients without DR in order to correlate these levels with the DR status.

\section{METHODS}

We prospectively evaluated and compared the TOS, TAC, and levels of IL- 6 and VEGF in the AH between 58 patients with DM and 28 patients without DM. This study was approved by the ethics committee of Sakarya University Education and Research Hospital (decision number: 12:16214662/050.01.04/74) and conformed to the provisions of the Declaration of Helsinki. Informed consent was obtained from all the participating patients in the study.
The patients who underwent cataract surgery between March 2014 and November 2014 were enrolled. The first group (control group) comprised patients without DM; the second group comprised diabetic patients without retinopathy (NDR); the third group comprised patients with nonproliferative DR (NPDR); and the fourth group comprised patients with proliferative DR (PDR). Patients who underwent extra- or intraocular surgery or laser photocoagulation and those who had retinal diseases, such as retinal detachment, senile macular degeneration, and all types of retinal vascular occlusions were excluded. Patients with pseudoexfoliation syndrome, glaucoma, uveitis, and pathologies that prevented retinal imaging, such as mature cataract and corneal opacity, were also excluded. The systemic exclusion criteria were hypertension, chronic hepatic disease, chronic pulmonary disease, rheumatic disease, oncologic disease, and chronic renal failure.

All patients underwent full ophthalmologic examination before cataract surgery. The anterior and posterior segments of all patients were examined by biomicroscopy; whereas intraocular pressure was measured with non-contact tonometer. Retinopathy was graded by a retina specialist prior to cataract surgery. For all patients, photographs and fluorescein angiography images of the fundus were taken after maximum dilation. Retinopathy grading was performed according to the ETDRS scoring system.

\section{AH sampling}

Only topical drops of cyclopentolate $\mathrm{HCl}$ 1.5\% (Sikloplejin ${ }^{\circledR}$, Abdi Ibrahım, Turkey) and tropicamide 1.5\% (Tropamid fort ${ }^{\circledR}$, Bilim Drug, Turkey) were applied to the eyes prior to surgery. At the beginning of surgery, 0.15-0.2 $\mathrm{mL}$ of $\mathrm{AH}$ was aspirated with a 27-gauge insulin syringe before cataract surgery was carried out using standard techniques. No complication occurred in any step of the AH sampling. The patients' barcodes were placed on the insulin syringe and information were recorded on their file. The $\mathrm{AH}$ samples were stored immediately at $-80^{\circ} \mathrm{C}$ until biochemical analysis.

\section{Measurement of TAC and TOS levels}

For each of the TAC and TOS measurements, $10 \mu \mathrm{L}$ of undilated $\mathrm{AH}$ was used and measured using an electronic micropipette. The TAC was measured by a colorimetric immunodiagnostic assay (IMANOX; AG/ GERMANY KC5100). Using as many microtiter strips as needed, the antioxidative capacity was determined based 
on the reaction of the antioxidants in the sample with a defined amount of exogenously provided hydrogen peroxide $\left(\mathrm{H}_{2} \mathrm{O}_{2}\right)$. After the antioxidants in the sample eliminated a certain amount of the provided $\mathrm{H}_{2} \mathrm{O}_{2}$, the residual $\mathrm{H}_{2} \mathrm{O}_{2}$ was determined calorimetrically by an enzymatic reaction; the samples were measured at 450 $\mathrm{nm}$ on a microtiter plate reader. Total oxidant stress was measured using a colorimetric immunodiagnostic assay (PerOx; AG/GERMANY KC5100) and the values were expressed in terms of $\mu \mathrm{mol} \mathrm{H}_{2} \mathrm{O}_{2}$ equiv/L. Finally, the oxidative stress index (OSI) was calculated using a specific formula, as follows:

OSI $=$ TOS $\left(\mu \mathrm{mol} \mathrm{H}_{2} \mathrm{O}_{2}\right.$ equiv/L) $\times 100 / \mathrm{TAC}(\mu \mathrm{mol}$ Trolox Equiv./L)

\section{Measurement of IL- 6 and VEGF levels}

VEGF was measured using Human VEGF-A enzyme-linked immunosorbent assay (ELISA) (ALPCO DIAGNOSTICS, USA) and IL- 6 concentration was measured quantitatively using Human IL-6 ELISA (ALPCO DIAGNOSTICS, USA). Briefly, using an electronic micropipette, $50 \mu \mathrm{L}$ of undilated $\mathrm{AH}$ samples and $50 \mu \mathrm{L}$ of standard diluent buffers were transferred onto a plate for measurements of VEGF and IL-6. Then, $50 \mu \mathrm{L}$ of biotin cojugate was added to this solution, followed by incubation for three hours. Thereafter, $100 \mu \mathrm{L}$ of streptavidin-HRP was added and incubated for 30 minutes. Finally, $100 \mu \mathrm{L}$ of $\mathrm{H}_{2} \mathrm{SO}_{4}$ was added at room temperature. Absorbance at $450 \mathrm{~nm}$ was read and measured using a KC4 reader control and data analysis software (Bio Tek instruments, USA).

\section{Measurement of HbA1c levels}

The serum HbA1c level, which reflects the mean glucose level in the preceding 2-3 months and is a useful indicator of the risk for diabetic complications, such as DR, were measured using high-performance liquid chromatography and was standardized according to the Diabetes Control and Complications.

\section{Statistical analysis}

Statistical analyses of the data were performed using SPSS software (SPSS Statistics, Version 22.0; IBM Corp., Armonk, NY, USA). Mann-Whitney U test with Bonferroni correction and Chi-square test were used for comparing the variance among the groups. Spearman's rank correlation coefficients were calculated to determine the relationships among the variants. A p-value of $<0.05$ was considered statistically significant.

\section{RESULTS}

This study enrolled 86 pairs of eyes of 86 patients who were grouped into four, as described above. The patients' age and sex were statistically similar among the groups. Table 1 shows the demographic characteristics of the subjects. Among the four groups, group 4 had the significantly lowest TAC level $(\mathrm{p}<0.05)$; group 1 had the significantly lowest TOS; and group 4 had the significantly highest OSI. Although the TOS increased in proportion to the severity of the DR, this increase was not statistically significant $(p>0.05)$.

The median VEGF level was significantly higher in group 4 (PDR group) than in group 1 (NDR group) $(p<0.05)$, but it was statistically different among groups $1,2$, and 3 ( $p>0.05)$. Additionally, an increase in VEGF levels positively correlated with the severity of the DR. The median IL-6 level was significantly higher in group 4 than in groups 1 and $2(p<0.05)$; there was no significant difference among the other groups. The mean CMT was significantly higher in group 4 than in groups 1 and $2(p<0.05)$; there was no significant difference among groups 1,2 , and 3 ( $p>0.05)$. The serum HbA1c levels were $6.1 \mathrm{mmol}, 6.9 \mathrm{mmol}, 8.7 \mathrm{mmol}$, and $8.25 \mathrm{mmol}$ in groups 1, 2, 3, and 4, respectively. The HbA1c level was significantly lower in group 1 than in the other three groups $(p<0.05)$ and significantly differed between groups 2 and $3(p<0.05)$. Table 2 and Figure 1 show the comparison of the TAC, TOS, OSI, IL-6, VEGF, median $\mathrm{CMT}$, and serum $\mathrm{HbA} 1 \mathrm{c}$ among the groups.

\section{DISCUSSION}

Hyperglycemia results in the overproduction of reactive oxygen species by various mechanisms that can damage various proteins, lipid membranes, and DNA and disrupt the normal cellular physiology ${ }^{(13)}$. The human retina is highly vulnerable to the damages caused

\begin{tabular}{lcccccc}
\multicolumn{7}{l}{ Table 1. Demographic characteristics of the subjects } \\
\hline & $\begin{array}{c}\text { Group 1 } \\
(\mathbf{n = 2 8 )}\end{array}$ & $\begin{array}{c}\text { Group 2 } \\
(\mathbf{n = 2 4 )}\end{array}$ & $\begin{array}{c}\text { Group 3 } \\
(\mathbf{n = 2 4 )}\end{array}$ & $\begin{array}{c}\text { Group 4 } \\
(\mathbf{n = 1 0 )}\end{array}$ & p-value \\
\hline Sex & Male & $14(50.0)$ & $11(45.8)$ & $12(50.0)$ & $6(60)$ & $\mathbf{0 . 9 0 4}$ \\
& Female & $14(50.0)$ & $13(54.2)$ & $12(50.0)$ & $4(40)$ & \\
Site & Right & $10(35.7)$ & $11(45.8)$ & $12(50.0)$ & $6(60)$ & $\mathbf{0 . 7 5 3}$ \\
& Left & $18(64.3)$ & $13(54.2)$ & $12(50.0)$ & $4(40)$ & \\
\multicolumn{2}{l}{ Age (years) } & 71.5 & $69[65-72]$ & $67[64-71.5]$ & $65[63-68]$ & $\mathbf{0 . 1 0 8}$ \\
& {$[66.5-74]$} & & & & \\
\hline
\end{tabular}

Statistical data were stated in terms of mean and percentage.

Age was stated in terms of mean [minimum and maximum value]

$\mathrm{p}<0.05$ was considered statistically significant 
Table 2. Comparison of the TAC, TOS, IL-6, VEGF, central macular thickness, and HbA1C levels among the groups

\begin{tabular}{|c|c|c|c|c|c|}
\hline & Group $1(n=28)$ & Group $2(n=24)$ & Group $3(n=24)$ & Group $4(n=10)$ & p-value \\
\hline TAC mmol TroloxEquiv. /L & $0.39[0,39-0.44]$ & $0.39[0.39-0.39]$ & $0.39[0.36-0.39]$ & $0.27[0.26-0.32]^{a, b, c}$ & $<0.001$ \\
\hline TOS $\mu \mathrm{mol} \mathrm{H}_{2} \mathrm{O}_{2}$ Equiv. /L & $4.05[2-8.28]$ & $11.14[3.01-40.24]^{\mathrm{a}}$ & $15[6.03-24.5]^{\mathrm{a}}$ & $25[20.24-52]^{\mathrm{a}}$ & $<0.001$ \\
\hline OSI & $1.03[0.52-1.86]$ & $1.15[0.73-5.13]$ & $3.59[1.2-5.77]^{\mathrm{a}}$ & $12.06[6.47-18.3]^{a, b, c}$ & $<0.001$ \\
\hline VEGF (pg/ml) & 50.85 [40.09-62.38] & $63.57[34.42-79.06]$ & 66.77 [48.04-131.7] & $95.89[75.85-149]^{a}$ & 0.006 \\
\hline IL6 (pg/ml) & $22.23[5.76-31.93]$ & $8.11[4.7-28.63]$ & $24.12[9.4-60.02]$ & $55.56[31.51-83.67]^{\text {a. b }}$ & 0.011 \\
\hline Central macular thickness $(\mu \mathrm{m})$ & $244.5[206.5-259.5]$ & $250[235.5-277]$ & 255 [230-289] & $304.5[290-359]^{\mathrm{d}, \mathrm{e}}$ & 0.003 \\
\hline $\mathrm{HbA} 1 \mathrm{C}(\mathrm{mmol})$ & $6.1[6-6.3]$ & $6.9[6.45-7.45]^{\mathrm{d}}$ & $8.7[7.75-9.25]^{\mathrm{d}, \mathrm{e}}$ & $8.25[7.9-9.3]^{d}$ & $<0.001$ \\
\hline
\end{tabular}

Data were stated in terms of mean [minimum and maximum value].

${ }^{\mathrm{a}}=$ significantly different from group $1(\mathrm{p}<0.05) ; \mathrm{b}=$ significantly different from group $2(\mathrm{p}<0.05) ;{ }^{\mathrm{c}}=$ significantly different from group $3(\mathrm{p}<0.05) ; \mathrm{d}=$ significantly higher than group 1 $(p<0.05) ;{ }^{e}=$ significantly higher than group $2(p<0.05)$.

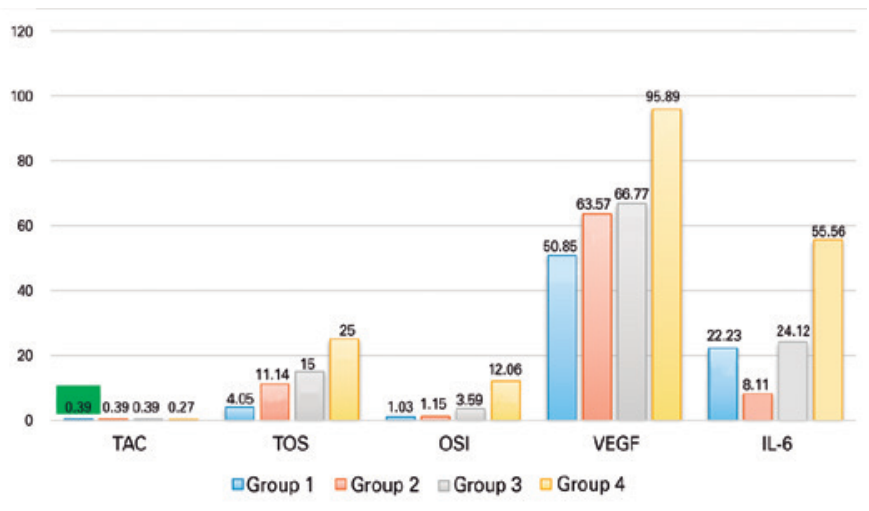

TAC= total antioxidant capacity, TOS: total oxidant status, OSI= oxidative stress index, VEGF = vascular endothelial growth factor, IL-6= interleukin- 6 See comment in PubMed Commons below.

Figure 1. Comparison of the TAC, TOS, OSI, VEGF, and IL- 6 levels among the groups.

by oxidative stress; therefore, oxidative stress plays an important role in the pathogenesis of $\mathrm{DR}^{(14)}$. Oxidative stress increases the flux of the poliol pathway, increases the expression of advanced glycosylation end products and their receptors, induces overactivation of protein kinase-C, leads to apoptosis of endothelial cells, destroys the macular pigment, and leads to inflammation ${ }^{(13)}$. Clinical trials and experimental results have provided rational basis for therapeutic interventions according to the balance between oxidants and antioxidants, which can either induce or slow disease progression. Therefore, antioxidative stress therapy may be implicated in the therapeutic strategy for $\mathrm{DR}^{(15)}$.

To reveal the effect of oxidative stress on DR, recent studies have measured oxidative stress markers in serum, $\mathrm{AH}$, and vitreus. Carrizales et al. established the correlation of the severity of NPDR with the serum markers of oxidative stress and mitochondrial function ${ }^{(15)}$. Moreover, they found that cases with severe retinopathy had a significant decrease in serum TAC levels but increased serum erythrocyte catalase and glutathion peroxidase activity. Türk et al. reported an increase in oxidative stress products and decrease in antioxidant enzyme activity in the plasma of DR patients ${ }^{(8)}$. They measured plasma levels of thiobarbituric acid reactive substances, superoxide dismutase, and catalase activities separately, but they did not classify the subgroups of DR. Saric et al. investigated selected oxidative markers, such as VEGF, lipid hydroperoxides (LPO), malondialdehit, and SOD in the vitreous and serum of patients with PDR and compared these with those of non-diabetic patients; they found that SOD and LPO were highly correlated in both the vitreous and serum in patients with PDR, compared with non-diabetic patients ${ }^{(10)}$. Their correlations suggested that monitoring their mutual alterations might be informative during PDR development. However, the use of selected oxidative markers may not represent the entire oxidative status and the interactions among all oxidative and antioxidative enzymes and products.

Caner et al. investigated the TAC and TOS levels in both plasma and AH of DR patients. They found a significant decrease in plasma TAC levels and an increase in plasma TOS levels, but there were no significant differences in the AH TAC and TOS levels ${ }^{(11)}$. Kırboğa et al. did not find a significant difference in the plasma levels of TAC and TOS between patients with DR and control subjects; the TOS level in the AH was significantly higher in the DR group, but the TAC level in the AH was not significantly different between both groups ${ }^{(16)}$. In these studies, DR was not classified into subgroups. However, it is important to note that the DR status might affect these parameters and cause variations in the results. 
Uçgun et al. reported that serum TAC decreased and TOS increased in nonproliferative DRP and proliferative DRP groups, in comparison with the control group ${ }^{(17)}$. Beyazyıldız et al. classified diabetic patients as those without retinopathy, those with nonproliferative DR, and those with proliferative DR. They compared the TAC and TOS levels in the $\mathrm{AH}$ among these groups and the control subjects and found that the highest levels of TAC were in the group of diabetic patients without retinopathy and that the TOS levels of diabetic patients without retinopathy and those with nonproliferative DR were significantly different from those of the other groups ${ }^{(18)}$. In our study, the highest levels of TAC were found in the control subjects and the highest levels of TOS were found in diabetic patients with proliferative DR. We also found similar TAC and TOS levels between diabetic patients without retinopathy and patients with NPDR.

In our study, the IL- 6 and VEGF levels in the AH were not significantly different among the NDR, NPDR, and control groups. Selim et al. also did not find a significant difference between the NDR and control groups but found a significant difference between the control and DR groups ${ }^{(19)}$. Zhou et al. found a correlation between the IL- 6 and VEGF levels in the AH and the grade of $\mathrm{DR}^{(20)}$. These results suggested that VEGF and IL- 6 might have effects on the development of DR. Kowluru et al. studied the relationship between oxidative stress and epigenetic modifications in the pathogenesis of DR, and found that the progression and development of DR might be affected by epigenetic factors and that oxidative stress may lead to mitochondrial DNA damage and worsen $\mathrm{DR}^{(21)}$.

The current study had some limitations, including the small sample size, especially group 4 , which might have affected our results.

In conclusion, the TAC levels in the $\mathrm{AH}$ were lower in patients with PDR. The TOS, VEGF, and IL-6 levels were found to slightly increase according to the DR status. Oxidative stress, IL-6, and VEGF seem to play important role in the pathogenesis of DR, especially in the proliferative type.

\section{REFERENCES}

1. Kempen JH, O'Colmain BJ, Leske MC, Haffner SM, Klein R, Moss $\mathrm{SE}$, et al. The prevalence of diabetic retinopathy among adults in the United States. Eye Diseases Prevalence Research Group. Arch Ophthalmol. 2004;122(4):552-63.

2. Rema M, Premkumar S, Anitha B, Deepa R, Pradeepa R, Mohan V. Prevalence of diabetic retinopathy in urban India: the Chennai Urban, Rural Epidemiology Study (CURES) eye study. Invest Ophthalmol Vis Sci. 2005;46(7):2328-33.
3. Du Y, Miller CM, Kern TS. Hyperglycemia increases mitochondrial superoxide in retina and retinal cells. Free Radic Biol Med. 2003; 35(11):1491-9.

4. Kowluru RA, Abbas SN. Diabetes-induced mitochondrial dysfunction in the retina. Invest Ophthalmol Vis Sci. 2003;44(12):5327-34.

5. Kowluru RA, Tang J, Kern TS. The effect of long-term administration of antioxidants on the development of retinopathy. Diabetes. 2001;50(8):1938-42.

6. Haskins K, Bradley B, Powers K, Fadok V, Flores S, Ling X, et al. Oxidative stress in type 1 diabetes. Acad Sci. 2003;1005(1):43-54.

7. Kowluru RA, Chan P-S. Oxidative stress and diabetic retinopathy. Exp Diabetes Res. United States. 2007;2007:43603.

8. Turk HM, Sevinc A, Camci C, Cigli A, Buyukberber S, Savli H, et al. Plasma lipid peroxidation products and antioxidant enzyme activities in patients with type 2 diabetes mellitus. Acta Diabetol. 2002;39(3):117-22.

9. Pan HZ, Zhang H, Chang D, Li H, Sui H. The change of oxidative stress products in diabetes mellitus and diabetic retinopathy. $\mathrm{Br}$ J Ophthalmol. 2008;92(4):548-51.

10. Saric VB, Landeka I, Saric B, Barberic M, Andrijasevic L, Cerovski $B$, et al. Levels of selected oxidative markers in the vitreous and serum of diabetic retinopathy patients. Mol Vis. 2015;21:669-4.

11. Caner C, Vural Özeç A, Aydın H, Topalkara A, Arıcı MK, Erdoğan H. Comparison of total oxidative stress, total antioxidant capacity, paraoxonase, arylesterase, lipid peroxidase levels in humor aquos and serum at diabetic and non-diabetic patients with cataract. Turk J Ophthalmol. 2012;42(1):47-52.

12. Mohamed Q, Gillies MC, Wong TY. Management of diabetic retinopathy: a systematic review. JAMA. 2007;298(8):902-16.

13. Behl T, Kaur l, Kotwani A. Implication of oxidative stress in progression of diabetic retinopathy. Surv Ophthalmol. 2016;61(2):187-96.

14. Wu Y, Tang L, Chen B. Oxidative stress: Implications for the development of diabetic retinopathy and antioxidant therapeutic perspectives. Oxid Med Cell Longev. 2014;2014:752387.

15. Carrizales AD, Gonzales JA, Romero EC, Arrevillaga GM, Hernandez DV, Godinez PP. Oxidants, antioxidants and mitochondrial function in non-proliferative diabetic retinopathy. J Diabetes. 2014;6: 167-75.

16. Kirboga K, Ozec AV, Kosker M, Dursun A, Toker MI, Aydin H, et al. The association between diabetic retinopathy and levels of ischemia-modified albumin, total thiol, total antioxidant capacity, and total oxidative stress in serum and aqueous humor. J Ophthalmol. 2014;2014:820853.

17. Uçgun HM, Sevinç A, Camcı C. Plasma lipid peroxidation products and antioxidant enzyme activities in patients with type 2 diabetes mellitus. Acta Diabetol. 2002;39(3):117-22.

18. Beyazyildiz E, Cankaya AB, Ergan E, Anayol MA, Ozdamar Y, Sezer $S$, et al. Changes of total antioxidant capacity and total oxidant status of aqueous humor in diabetes patients and correlations with diabetic retinopathy. Int J Ophthalmol. 2013;6(4):531-6.

19. Selim KM, Sahan D, Muhittin T, Osman C, Mustafa O. Increased levels of vascular endothelial growth factor in the aqueous humor of patients with diabetic retinopathy. Ind J Ophthalmol. 2010; 58(5):375-9.

20. Zhou L, Sun H, Xu J, Kang J. [Level of vascular endothelial growth factor and interleukin-6 in aqueous humor in diabetic retinopathy patients.]. Yan Ke Xue Bao. 2010;25(1):26-30. Chinese.

21. Kowluru RA, Kowluru A, Mishra M, Kumar B. Oxidative stress and epigenetic modifications in the pathogenesis of diabetic retinopathy. Prog Retin Eye Res. 2015;48:40-61. 